\title{
Electroporation-Based Technologies and Treatments
}

\author{
Damijan Miklavčič $\cdot$ Lluis M. Mir • \\ P. Thomas Vernier
}

Published online: 24 July 2010

(C) Springer Science+Business Media, LLC 2010

When a cell is exposed to a sufficiently large electric field, even for a very short time, its plasma membrane is changed so that molecules that normally cross the membrane only in minute amounts can more readily pass through the barrier. This phenomenon was first described by Neumann and Rosenheck (1972) in this journal. A decade later gene transfer was achieved by means of electroporation (Neumann et al. 1982). This technique is now widely used in laboratories around the world and is gaining even more attention in recent years as a method for introducing foreign genes into cells in vivo (Mir 2009), with good prospects for use in a clinical setting (Daud et al. 2008). Electroporation has been used in the last decade also for improving cancer drug delivery to cells. Preclinical investigations in the late 1980s (Orlowski et al. 1988; Mir et al. 1991) were followed by the first clinical trial in 1991 (Mir et al. 1991; Belehradek et al. 1993). Electrochemotherapy as an effective and safe local treatment for cutaneous and subcutaneous tumors (Marty et al. 2006; Serša and Miklavčič 2008) is now accepted in a number of

D. Miklavčič

Faculty of Electrical Engineering, University of Ljubljana,

Tržaška 25, 1000 Ljubljana, Slovenia

e-mail:damijan.miklavcic@fe.uni-lj.si

L. M. Mir

UMR 8203 Vectorology and Anti-cancerous Therapeutics, Institute Gustave-Roussy, 39 Rue Camille Desmoulins, 94805 Villejuif, France

e-mail: luismir@igr.fr

P. Thomas Vernier $(\square)$

MOSIS, Information Sciences Institute, Viterbi School

of Engineering, University of Southern California,

Los Angeles, CA, USA

e-mail: vernier@mosis.com countries, is routinely employed in more than 60 cancer treatment centers and is being further developed for treating more deep-seated tumors (Miklavcic et al. 2010).

Electroporation can be used in all kinds of isolated cells as well as in tissues. The electric field to which one exposes the target cell has to be of sufficient strength and the exposure of sufficient duration. The magnitude of the electric field to be used depends on cell type, size, orientation and density; pulse duration; and number of pulses. The selection of pulse parameters is influenced also by the size and type of molecule to be internalized. Depending on the location and size of the targeted tissue, electric pulses will be delivered via appropriate electrodes chosen among a number of different types. Geometry and positioning of electrodes affect electric field distribution, which is important for effective in vivo electropermeabilization (Miklavčič et al. 1998, 2000).

Strategies for the treatment of malignancies based on direct effects of pulsed electric fields on cells, independent of the induced influx of pharmacological or genetic material, are also under development. These include tumor ablation by irreversible electroporation (Al-Sakere et al. 2007) and by the application of intense (MV/m), nanosecond-duration pulses, which induce apoptosis and destruction of the tumor vascularization (Nuccitelli et al. 2006).

This special issue of the Journal of Membrane Biology features selected peer-reviewed reports from investigators currently active in electroporation-related research who attended the Fourth International Scientific Workshop and Postgraduate Course on Electroporation-Based Technologies and Treatments in Ljubljana, Slovenia, in November 2009. This unique working conference at the University of Ljubljana has been organized every 2 years since the first one in 2003. More than 200 participants from 21 countries 
have attended the first four workshops. The targeted audience includes all those interested in applications of electroporation in vitro, in vivo and in the clinic.

The aim of the lectures at the workshop and course is to provide participants with sufficient theoretical background and practical knowledge to allow them to use electroporation effectively in their working environments. We also invite lecturers who present the newest developments in the field. However, probably the greatest attraction is the practical laboratory component of the course, where, in laboratories at the University of Ljubljana, participants can perform by themselves electroporation of planar lipid bilayers, measurement of induced transmembrane potential, electrotransfection of cells and fusion of cells by electroporation. In addition, computing facilities are provided for practical exercises in molecular dynamics simulations and numerical modeling of electric field distributions.

The next Workshop and Course on Electroporation-based Technologies and Treatments is planned for November 13-19, 2011. Details, including programs and proceedings from previous years, can be found at http://www. cliniporator.com/ect.

\section{References}

Al-Sakere B, Andre F, Bernat C, Connault E, Opolon P, Davalos RV, Rubinsky B, Mir LM (2007) Tumor ablation with irreversible electroporation. PLoS ONE 2:e1135

Belehradek M, Domenge C, Luboinski B, Orlowski S, Belehradek J Jr, Mir LM (1993) Electrochemotherapy, a new antitumor treatment: first clinical phase I-II trial report. Cancer 72:3694-3700

Daud A, DeConti RC, Andrews S et al (2008) Phase I trial of interleukin-12 plasmid electroporation in patients with metastatic melanoma. J Clin Oncol 26:5896-5903
Marty M, Sersa G, Garbay JR, Gehl J, Collins C, Snoj M, Billard V, Geertsen P, Larkin J, Miklavcic D, Pavlovic I, Paulin-Kosir S, Cemazar M, Morsli N, Soden D, Rudolf Z, Robert C, O'Sullivan G, Mir LM (2006) Electrochemotherapy—a simple, highly effective and safe treatment of cutaneous and subcutaneous metastases: results of ESOPE (European Standard Operating Procedures for Electrochemotherapy) study. Eur J Cancer Suppl $4: 3-13$

Miklavcic D, Snoj M, Zupanic A, Kos B, Cemazar M, Kropivnik M, Bracko M, Pecnik T, Gadzijev E, Sersa G (2010) Towards treatment planning and treatment of deep-seated solid tumors by electrochemotherapy. Biomed Eng Online 9:10. doi:10.1186/ 1475-925X-9-10

Miklavčič D, Beravs K, Šemrov D, Čemažar M, Demšar F, Serša G (1998) The importance of electric field distribution for effective in vivo electroporation of tissues. Biophys J 74:2152-2158

Miklavčič D, Šemrov D, Mekid H, Mir LM (2000) A validated model of in vivo electric field distribution in tissues for electrochemotherapy and for DNA electrotransfer for gene therapy. Biochim Biophys Acta 1519:73-83

Mir LM (2009) Nucleic acids electrotransfer-based gene therapy (electrogenetherapy): past, current, and future. Mol Biotechnol 43:167-176

Mir LM, Belehradek M, Domenge C, Orlowski S, Poddevin B, Belehradek J Jr, Schwaab G, Luboinski B, Paoletti C (1991) Electrochemotherapy, a novel antitumor treatment: first clinical trial [in French]. C R Acad Sci III 313:613-618

Neumann E, Rosenheck K (1972) Permeability changes induced by electric impulses in vesicular membranes of chromaffin granules. J Membr Biol 10:279-290

Neumann E, Schaefer-Ridder M, Wang Y, Hofschneider PH (1982) Gene transfer into mouse lyoma cells by electroporation in high electric fields. EMBO J 1:841-845

Nuccitelli R, Pliquett U, Chen X, Ford W, Swanson RJ, Beebe SJ, Kolb JF, Schoenbach KH (2006) Nanosecond pulsed electric fields cause melanomas to self-destruct. Biochem Biophys Res Commun 343:351-360

Orlowski S, Belehradek J Jr, Paoletti C, Mir LM (1988) Transient electropermeabilization of cells in culture: increase of the cytotoxicity of anticancer drugs. Biochem Pharmacol 37:47274733

Serša G, Miklavčič D (2008) Electrochemotherapy of tumours [video article]. J Vis Exp 22:1038. doi:10.3791/1038 